\title{
RANCANG BANGUN SISTEM ELECTRONIC NOSE (E-NOSE) UNTUK DETEKSI SAMPEL KANKER PAYUDARA BERBASIS MIKROKONTROLER ARDUINO UNO
}

\author{
Gina Yulia Sari, Wildian, Nini Firmawati* \\ Jurusan Fisika, FMIPA, Universitas Andalas, Limau Manis, Padang, 25163 \\ *Korespondensi ke: firmawatinini@gmail.com \\ ( Diterima:21 Januari 2018; Direvisi: 21 Februari 2018; Diterbitkan: 01 Maret 2018 )

\begin{abstract}
ABSTRAK
Telah dilakukan rancang bangun sistem electronic nose (e-nose) yang terdiri dari 4 sensor gas, yaitu TGS822 (alkohol), TGS826 (amonia), TGS2600 (kontaminasi udara), dan TGS2602 (kontaminasi udara). Sistem e-nose ini digunakan untuk melihat respon sensor terhadap urin positif kanker payudara, negatif kanker payudara dan air. Data keluaran ke empat sensor di olah menggunakan modul mikrokontroler Arduino Uno, disimpan dan ditampilakn pada perconal computer menggunakan perangkat lunak LabVIEW. Sistem e-nose ini diujikan menggunakan 7 sampel (3 terhadap urin positif kanker payudara, 3 urin negatif kanker payudara dan air). Setiap sampel diujikan sebanyak 9 kali pengujian yang dilakukan selama 3 hari dengan setiap harinya sebanyak 3 kali pengujian. Hasil pengolahan akhir menunjukan bahwa sistem e-nose ini dapat membedakan antara sampel urin positif kanker, urin negatif kanker dan air terlihat dari pola radar yang terbentuk dari keempat sensor.

Kata Kunci : kanker payudara, electronic nose (e-nose), urin, sensor gas TGS.
\end{abstract}

\begin{abstract}
The electronic nose (e-nose) system has been designed for 4 gas sensors, namely TGS822 (alcohol), TGS826 (ammonia), TGS2600 (air contamination), and TGS2602 (air contamination). This e-nose system is used to view the sensor response to the positive urine of breast cancer, negative breast and water cancers. The four sensor output data is processed using the Arduino Uno microcontroller module, stored and displayed on the perconal computer using the LabVIEW software. This e-nose system is tested using 7 samples (3 positive urine of breast cancer, 3 negative urine breast cancer and water). Each sample was tested 9 times the test done for 3 days with 3 times the test. The final treatment results show that this e-nose system can distinguish between samples positive urine of cancer, the negative urine of cancer and water seen from the radar pattern formed from the four sensors.
\end{abstract}

Keywords : breast cancer, electronic nose (e-nose), urine, TGS sensors gas. 


\section{PENDAHULUAN}

Electronic nose disingkat dengan $e$-nose yang merupakan sistem penciuman buatan untuk menganalisis, mengenali dan mendeteksi bau yang sederhana maupun kompleks dan senyawa yang menguap (Zakaria, 2012). E-nose merupakan salah satu peranti yang meniru cara kerja penciuman manusia. E-nose telah banyak diaplikasikan dalam berbagai bidang, seperti industri makanan, minuman, kimia, pertahanan, kesehatan, dan lain-lain. Di industri makanan, e-nose dapat digunakan untuk indentifikasi aroma yang berguna dalam pemantauan proses produksi, seperti penelitian tentang klasifikasi jamur patogen yang menyerang pertanian buah stroberi (Pan dkk, 2014), evaluasi kesegaran, seperti deteksi tingkat kesegaran daging (Zhang dkk, 2008). Di dalam bidang kesehatan, $e$ nose ini telah diterapkan pada pengukuran langsung aroma urin untuk mendeteksi diabetes (Siyang dkk, 2012), kanker prostat (Amico dkk, 2012), dan kanker kandungan kemih (Willis dkk, 2011).

Namun, belum ditemukan penelitian yang membahas e-nose untuk deteksi kanker payudara. Urin dipilih sebagai sampel karena pengambilannya yang mudah dan urin telah menjadi sampel dengan konten informatif yang kaya jika dianalisis melalui e-nose (Amico dkk, 2012). Dan diketahui sel-sel kanker melepaskan penanda bio-molekuler ke dalam darah selama pertumbuhan mereka, yang dapat memberikan simbol yang berguna dalam diagnosis kanker melalui urin $(\mathrm{Li}, 2014)$.

Alat yang dirancang pada penelitian ini menggunakan 4 sensor gas, yaitu TGS 822 untuk deteksi alkohol, TGS 826 sebagai deteksi amonia, dan digunakan 2 sensor lagi untuk deteksi kontaminasi udara yaitu TGS 2600, dan TGS 2602. Sensor gas yang digunakan ini merupakan tipe jenis sensor semikonduktor dan merupakan perangkat yang mampu mengubah kuantitas bahan kimia menjadi sinyal listrik yang berhubungan dengan konsentrasi partikel tertentu seperti atom, molekul atau ion dalam gas atau cairan (Peris dan Gilabert, 2009).

Penelitian ini bertujuan menghasilkan model desain alat e-nose yang diterapkan untuk pengujian urin positif kanker payudara dengan membandingkan pada urin negatif kanker payudara serta air secara non-invasive, yaitu alat yang dapat membedakan urin positif dan negatif kanker payudara tanpa harus menyakiti pasien. Alat ini menggunakan sistem $e$ nose dengan menampilkan hasil pengukurannya pada perconal computer. Sehingga dalam perkembangannya rancangan e-nose ini dapat digunakan di klinik-klinik kesehatan dan puskesmas sebagai deteksi kanker payudara.

\section{METODE PENELITIAN}

Rancang bangun sistem e-nose ini dilakukan di laboratorium Elektronika dan Instrumentasi Jurusan Fisika FMIPA Universitas Andalas. Perancangan sistem e-nose ini terdiri dari perangkat keras dan perangkat lunak.

\subsection{Perancangan Perangkat Keras}

Perancangan perangkat keras e-nose terdiri dari, rangkain sensor, rangkaian LCD, dan rangkaian relay sebagai saklar untuk kipas dan pemanas. Pada penelitian ini diperlukan catudaya $+5 \mathrm{~V}$ dc sebagai sumber tegangan Arduino Uno, 4 sensor, serta LCD dan $+12 \mathrm{~V}$ dc untuk sistem relay. Bentuk rancangan dapat dilihat pada Gambar 1.

2 DOI: $\underline{10.25077 / j i f .10 .1 .1-10.2018}$ 


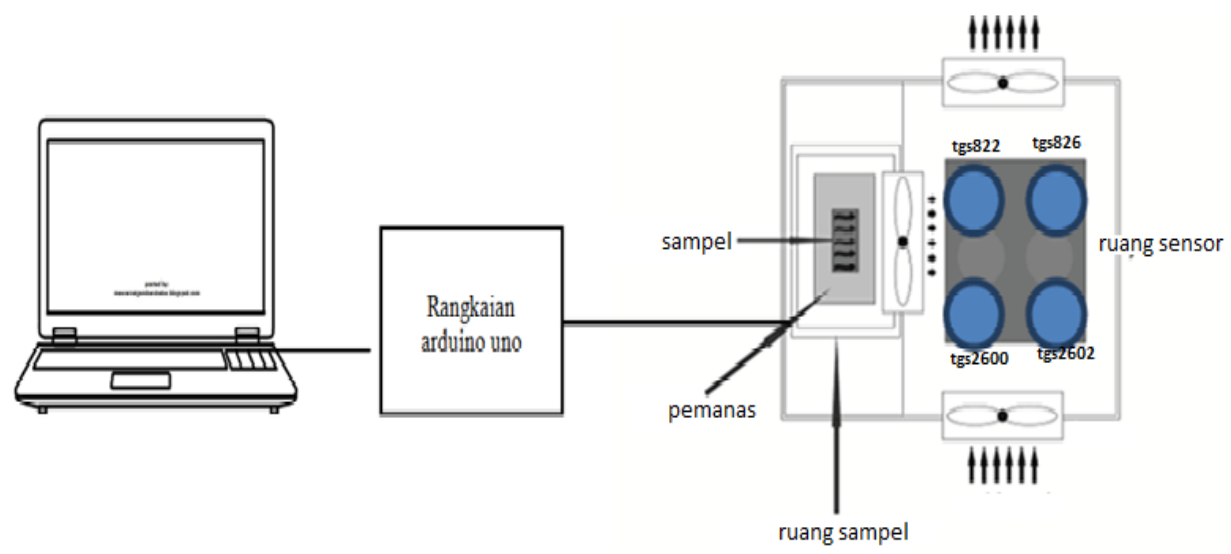

Gambar 1 Rancangan perangkat keras

Gambar 1 memperlihatkan rancangan keseluruhan dari sistem e-nose yang terdiri dari 3 bagian yaitu, bagian penampil, bagian rangkaian dan bagian detektor. Bagian penampil berupa perconal computer sebagai penampil dan penyimpan data pengujian. Bagian rangkain ini berupa perangkaian pada mikrokontroler sebagai pengolah data dari detektor sebelum ditampilkan dan tersimpan pada perconal computer.

Pada perancangan perangkat keras terdapat sebuah box yang terdiri dari dua ruang yaitu ruang sampel dan ruang sensor. Pada rancangan perangkat keras ini digunakan 3 buah kipas,dengan fungsinya 1 kipas yang berada di antara ruang sampel dan ruang sensor sebagai pengalir udara dari ruang sampel menuju ruang sensor dan 2 kipas yang berada pada ruang sensor yang dirancang sebagai pembersih bagian ruang sensor. Pada ruang sampel terdapat sebuah elemen paltier yang digunakan sebagai pemanas sampel untuk membantu mempercepat penguapan sampel. Sampel urin dan air yang diujikan diletakkan pada ruang sampel yang dimasukkan pada wadah berukuran $2 \mathrm{~cm} \times 2 \mathrm{~cm} \times 1 \mathrm{~cm}$ yang terbuat dari aluminium foil.

\subsection{Perancangan Perangkat Lunak}

Dalam menjalankan rancangan sistem e-nose ini dibutuhkan suatu pengontrol berupa program. Pada rancangan sistem e-nose ini digunakan 2 jenis program yaitu program pengontrol menggunakan software arduino dan sebagai data logger menggunakan software LabVIEW. Pembuatan program bahasa labVIEW berbeda dari pembuatan bahasa program lainnya, yaitu bahasa program berbasis grafis atau diagram blok, seperti pada Gambar 2. 


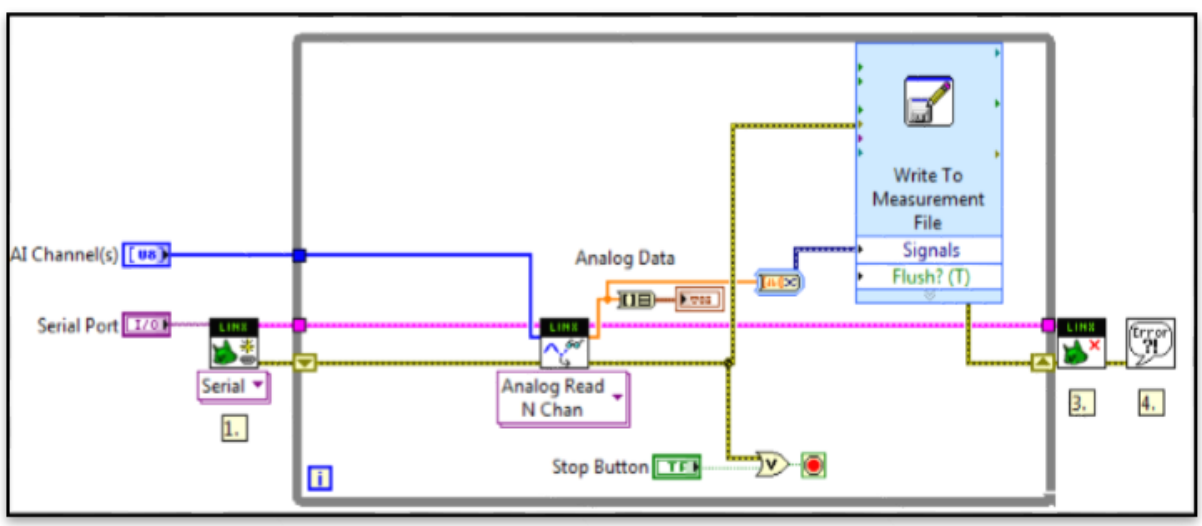

Gambar 2 Program LabVIEW untuk data logger sistem e-nose

\subsection{Tahapan penelitian}

Setelah selesai melakukan perancangan sistem $e$-nose yang terdiri dari perangkat keras dan perangkat lunak, dilakukan pengujian dengan beberapa langkah pengerjaan sebagai berikut:

1. Preparasi sampel, masing-masing sampel diukur dengan volume yaitu $2 \pm 0,05 \mathrm{ml}$ menggunakan gelas ukur. Setelah diukur, masing-masing sampel tersebut dimasukkan kedalam wadah yang terbuat dari aluminium foil. Wadah dibuat dengan panjang $4 \mathrm{~cm}$, lebar $4 \mathrm{~cm}$ dan tinggi $1 \mathrm{~cm}$. Setiap kali pengukuran, wadah sampel diganti dengan yang baru agar tidak ada sisa bahan pada wadah yang digunakan sebelumnya. Tidak ada tambahan senyawa lain dalam sampel.

2. Pengambilan data, ada beberapa tahap yang dilakukan yaitu:

a. Mencari nilai baseline awal sistem.

Untuk mencapai suhu kerja sensor dan titik stabil luaran sensor terlebih dahulu electronic nose dinyalakan selama 20 menit. Setelah itu, perekaman data dilakukan ketika sensor hanya terpapar udara bebas. Respon luaran sensor terhadap udara bebas digunakan sebagai data baseline.

b. Pengujian sampel

Setelah pengambilan data baseline dilakukan, sampel yang sudah dimasukkan ke dalam wadah yang terbuat dari aluminium foil diletakkan ke dalam ruang sampel. Pada penelitian ini proses sensing diatur selama 1 menit dan proses flushing diatur selama 2 menit.

c. Pemulihan respon sensor

Setelah pengambilan data dilakukan, ruang sampel kemudian dibersihkan. Setelah itu dilakukan proses flushing selama 1 menit. Hal ini dimaksudkan untuk membersihkan sensor dari aroma sampel sebelumnya.

3. Pengolahan data respon luaran sensor yang dihasilkan pada langkah dua dilakukan dengan pengambilan nilai maksimum setiap pengujian. Hal ini bertujuan untuk mengetahui apakah Electronic Nose dapat mengenali sampel urin kanker payudara, urin negatif kanker payudara serta air. 


\section{HASIL DAN DISKUSI}

\subsection{Rancang bangun sistem electronic nose (e-nose)}

Rancang bangun sistem e-nose untuk deteksi kanker payudara berbasis mikrokontroler Arduino Uno telah selesai dilakukan. Perancangan alat ini dilakukan dengan beberapa pengujian secara bertahap. Pengujian dilakukan terhadap perangkat keras dan perangkat lunak, kemudian pengujian alat secara keseluruhan. Rangkaian keseluruhan dari alat yang sudah dirancang dapat dilihat pada Gambar 3.

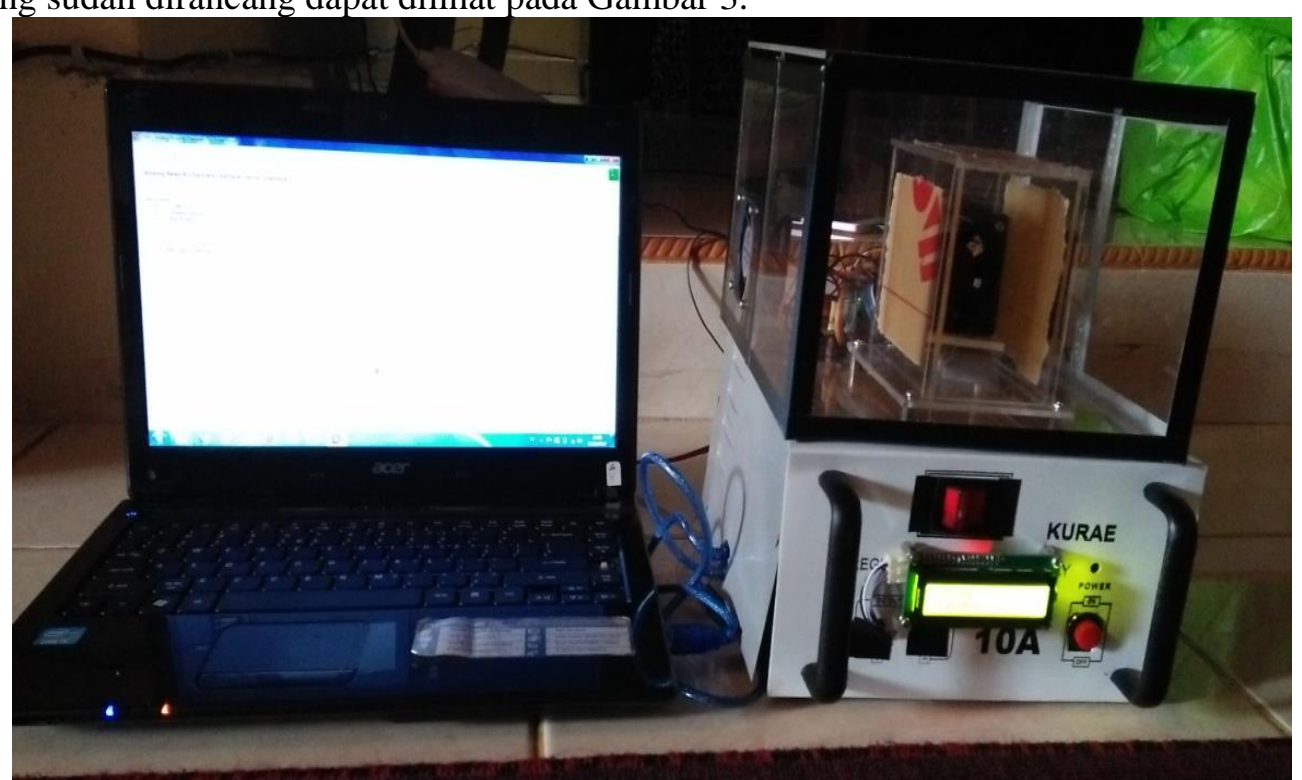

Gambar 3 Bentuk fisik alat secara keseluruhan

Pada Gambar 3 dari bentuk fisik alat secara keseluruhan terdapat sebuah LCD. Pada rancangan $e$-nose ini digunakan sebuah LCD untuk menampilkan proses yang sedang berlansung pada sistem $e$-nose yaitu saat proses flushing maupun sensing.

\subsection{Hasil Pengujian Rancang Bangun sistem electronic nose (e-nose)}

Pengujian rancang bangun sitem e-nose dilakukan menggunakan 7 sampel, yaitu 3 sampel urin positif kanker payudara, 3 sampel urin negatif kanker payudara, dan 1 sampel air. Masing-masing sampel diujikan sebanyak 3 hari pengulangan pengambilan data dengan masing-masing hari juga dilakukan pengujian sebanyak 3 kali pengujian untuk setiap sampel. Alat $e$-nose ini memiliki 3 tahapan perekaman data yang dilakukan selama 5 menit, yaitu 2 menit pada flushing pertama 1 menit sensing dan 2 menit flusing akhir. Setiap proses yang sedang berlangsung dari alat akan ditampilkan pada LCD. Hasil dari pengujian sistem $e$-nose pada 1 hari dapat dilihat pada Tabel 1 . 
Tabel 1. Data pengujian sistem $e$-nose pada hari ke 1

\begin{tabular}{|c|c|c|c|c|c|}
\hline \multicolumn{6}{|l|}{ Hari ke 1} \\
\hline \multirow{2}{*}{ Sampel } & \multirow{2}{*}{$\begin{array}{l}\text { Pengambilan } \\
\text { data ke- }\end{array}$} & \multicolumn{4}{|c|}{ Tegangan Keluaran Sensor (V) } \\
\hline & & TGS822 & TGS826 & TGS2600 & TGS2602 \\
\hline \multirow{3}{*}{$\begin{array}{c}\text { Urin A } \\
\text { Positif kanker }\end{array}$} & 1 & 0,117187 & 0,073242 & 1,928711 & 0,273437 \\
\hline & 2 & 0,141602 & 0,073242 & 2,03125 & 0,268555 \\
\hline & 3 & 0,112305 & 0,078125 & 1,845703 & 0,249023 \\
\hline \multirow{3}{*}{$\begin{array}{c}\text { Urin B } \\
\text { Positif kanker }\end{array}$} & 1 & 0,117187 & 0,073242 & 1,870117 & 0,253906 \\
\hline & 2 & 0,117187 & 0,078125 & 1,870117 & 0,258789 \\
\hline & 3 & 0,126953 & 0,078125 & 1,884766 & 0,307617 \\
\hline \multirow{3}{*}{$\begin{array}{c}\text { Urin C } \\
\text { Positif kanker }\end{array}$} & 1 & 0,146484 & 0,078125 & 2,041016 & 0,34668 \\
\hline & 2 & 0,131836 & 0,078125 & 1,982422 & 0,302734 \\
\hline & 3 & 0,141602 & 0,078125 & 2,104492 & 0,297852 \\
\hline \multirow{3}{*}{$\begin{array}{c}\text { Urin A } \\
\text { Negatif kanker }\end{array}$} & 1 & 0,620117 & 0,112305 & 2,172852 & 0,302734 \\
\hline & 2 & 0,625 & 0,151367 & 2,22168 & 0,322266 \\
\hline & 3 & 0,615234 & 0,117187 & 2,241211 & 0,332031 \\
\hline \multirow{3}{*}{$\begin{array}{c}\text { Urin B } \\
\text { Negatif kanker }\end{array}$} & 1 & 0,644531 & 0,117187 & 2,255859 & 0,322266 \\
\hline & 2 & 0,639648 & 0,117187 & 2,265625 & 0,317383 \\
\hline & 3 & 0,654297 & 0,117187 & 2,260742 & 0,3125 \\
\hline \multirow{3}{*}{$\begin{array}{c}\text { Urin C } \\
\text { Negatif kanker }\end{array}$} & 1 & 0,546875 & 0,107422 & 2,184766 & 0,239258 \\
\hline & 2 & 0,541992 & 0,102539 & 2,184766 & 0,239258 \\
\hline & 3 & 0,546875 & 0,107422 & 2,175 & 0,239258 \\
\hline \multirow{3}{*}{ Aquades } & 1 & 0,429883 & 0,037422 & 1,914062 & 0,229492 \\
\hline & 2 & 0,381055 & 0,037422 & 1,865234 & 0,234375 \\
\hline & 3 & 0,371289 & 0,032539 & 1,850586 & 0,229492 \\
\hline
\end{tabular}

Tabel 1 merupakan pengambilan data untuk pengujian e-nose pada hari ke 1 dengan memilih nilai maksimum untuk setiap pengujian. Pengujian ketujuh sampel seperti pada tabel 1 dilakukan dengan prosedur yang sama untuk hari kedua dan hari ketiga.

Pada penelitian ini dipilih penyajian data dalam bentuk pola radar untuk melihat respon rancangan $e$-nose terhadap sampel. Pola radar yang terbentuk akan memperlihatkan pola yang sama ditandakan saat saling berimpitnya pola radar pada sampel yang sama, dan akan terlihat pola radar yang berbeda pada sampel yang berbeda.

Hasil pengambilan data untuk kurva radar yang dibentuk berdasarkan pada nilai maksimum data dari masing-masing keluaran sensor pada hari ke 1,2, dan 3dari ketujuh sampel uji. Untuk melihat respon sistem e-nose terhadap sampel pembentukan kurva radar dibagi menjadi tiga tahapan. Pertama untuk melihat respon sensor terhadap satu sampel di hari yang sama dengan 3 kali pengujian, dapat dilihat pada Gambar 4.1 Gambar 4.7. Kedua untuk melihat respon sensor terhadap sampel yang sama pada hari yang berbeda, dalam penelitian ini diujikan 3 hari dapat dilihat pada Gambar 5.1- Gambar 5.7 . 
1. Kurva radar masing-masing sampel pada masing-masing harinya.

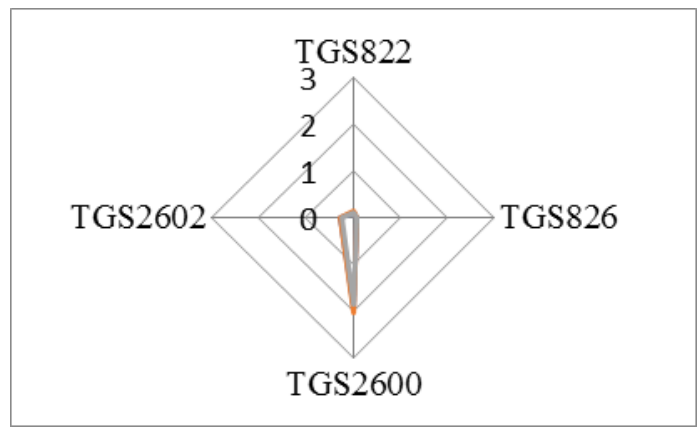

Gambar 4.1 Radar urin A positif kanker payudara hari ke-1

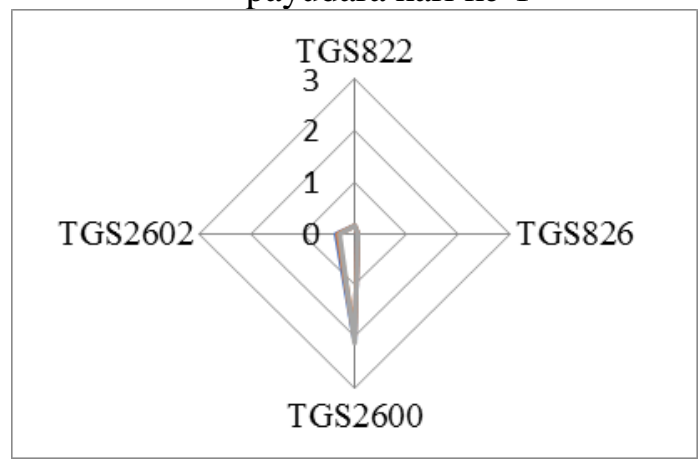

Gambar 4.3 Radar urin $C$ positif kanker payudara hari ke-1

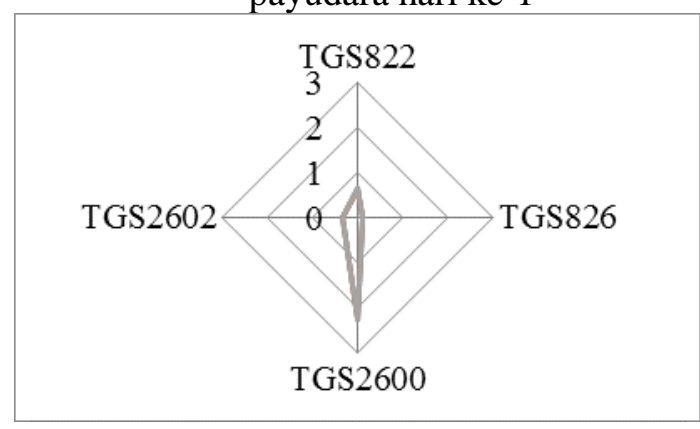

Gambar 4.5 Radar urin B negatif kanker payudara hari ke-1

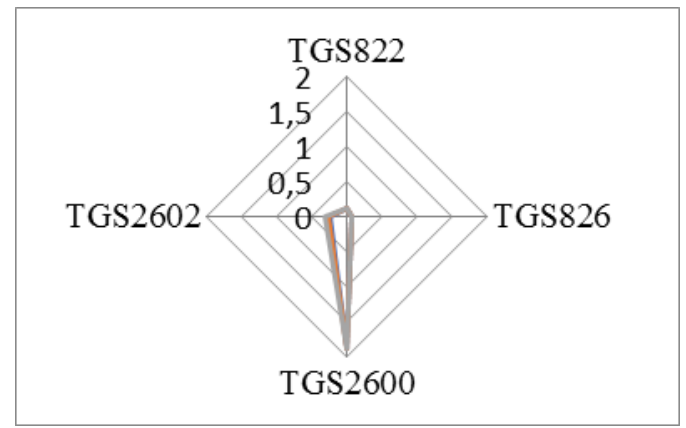

Gambar 4.2 Radar urin B positif kanker payudara hari ke-1

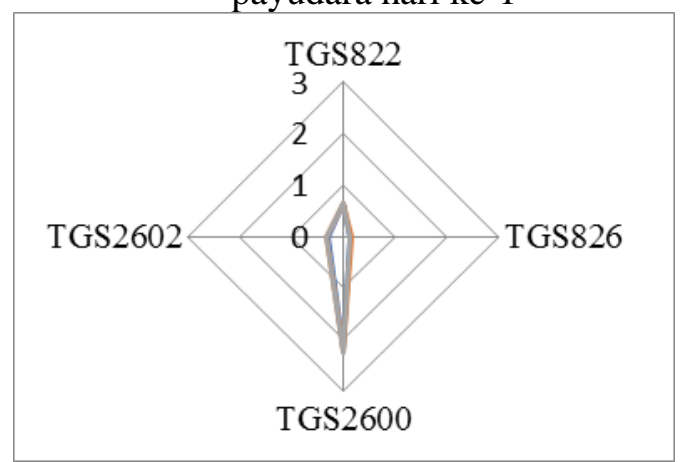

Gambar 4.4 Radar urin A negatif kanker payudara hari ke-1

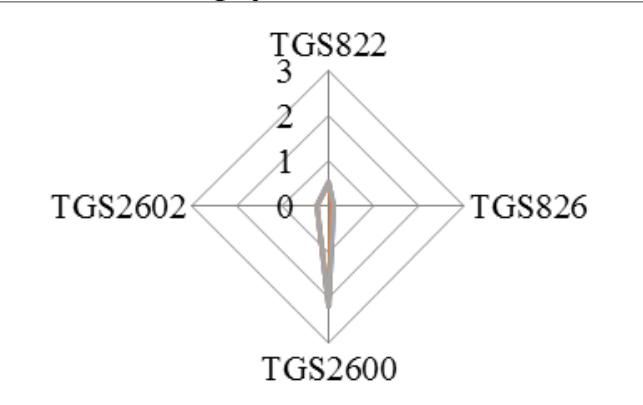

Gambar 4.6 Radar urin C negatif kanker payudara hari ke-1

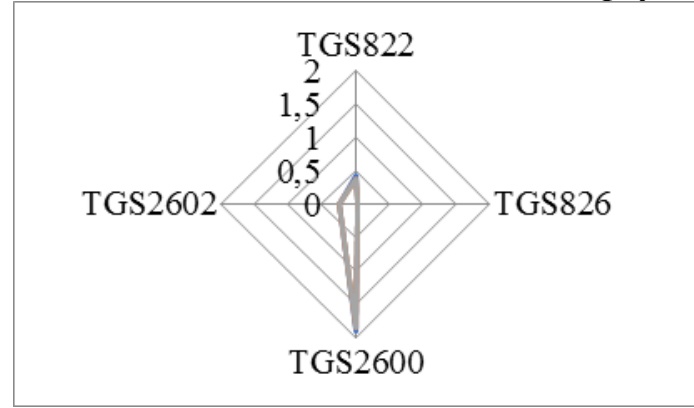

Gambar 4.7 Radar aquades hari ke-1 
Gambar hasil keluaran sensor untuk 3 kali pengulangan pengujian dalam satu hari dari masing-masing sampel dapat memperlihatkan bahwa setiap pengulangan pengujian pada setiap sampel yang sama $e$-nose mampu menghasilkan nilai yang hampir sama terlihat dari ketiga data setiap pengujian yang saling berimpit.

2. Kurva radar masing-masing sampel untuk ketiga harinya.

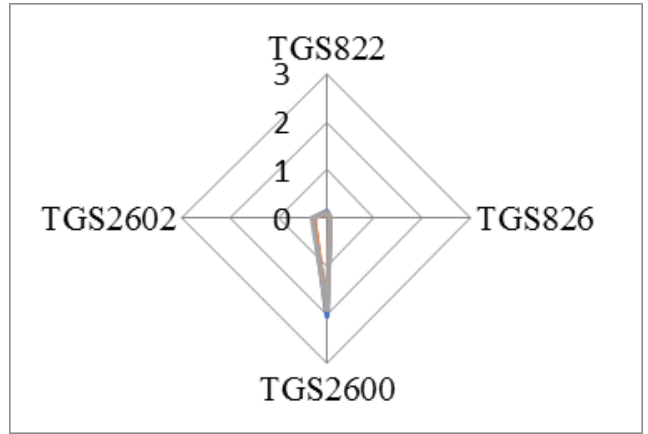

Gambar 5.1 Radar urin A positif kanker payudara 3 hari pengujian

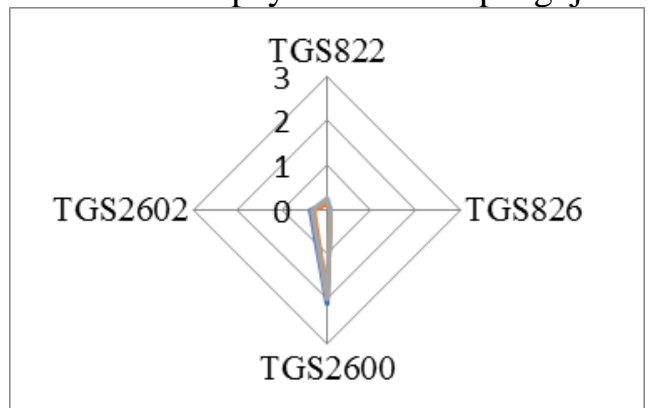

Gambar 5.3 Radar urin C positif kanker payudara 3 hari pengujian

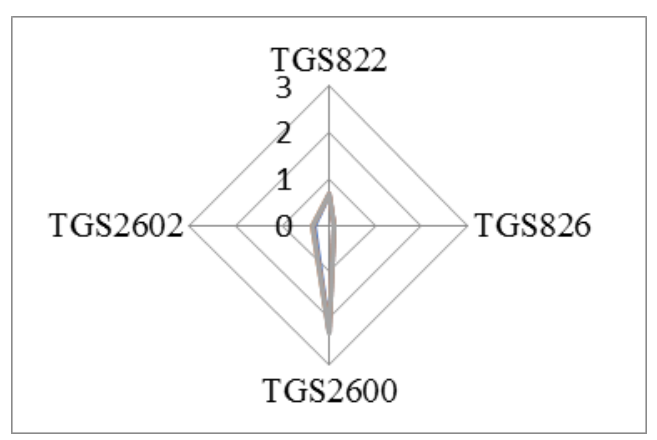

Gambar 5.5 Radar urin B negatif kanker payudara 3 hari pengujian

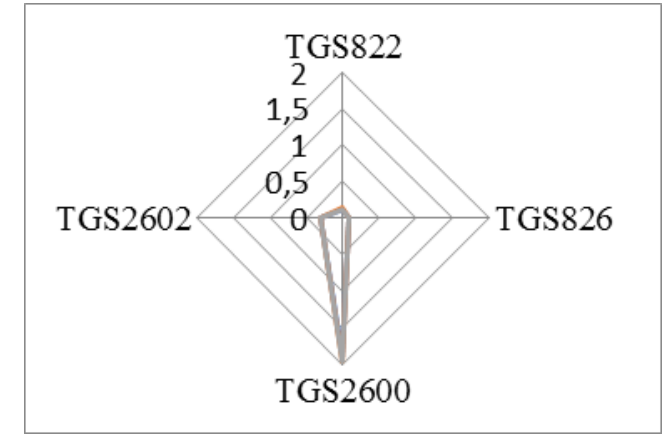

Gambar 5.2 Radar urin B positif kanker payudara 3 hari pengujian

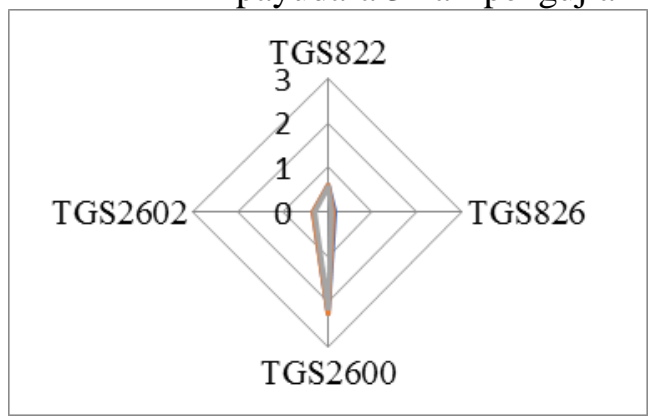

Gambar 5.4 Radar urin A negatif kanker payudara 3 hari pengujian

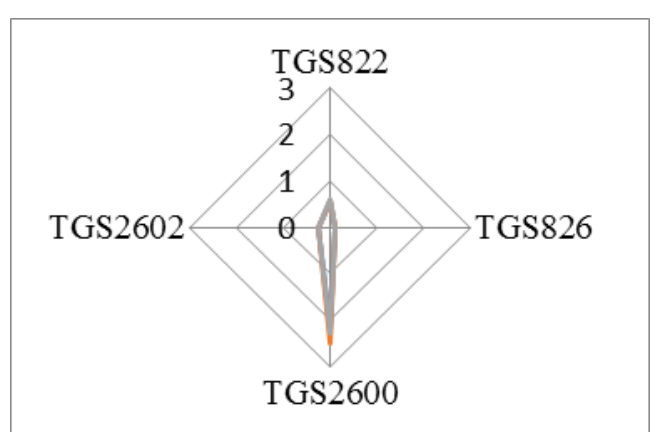

Gambar 5.6 Radar urin C negatif kanker payudara 3 hari pengujian 


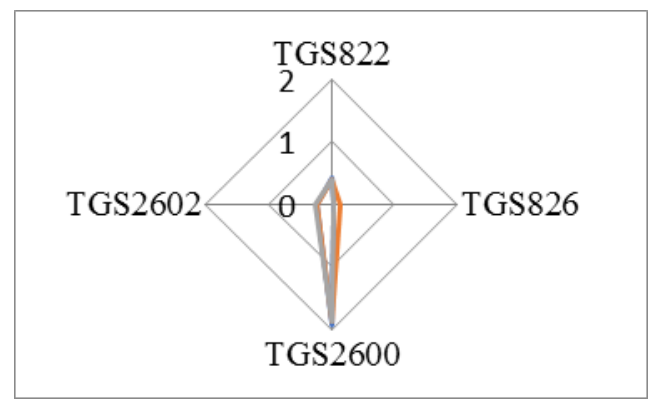

Gambar 5.7 Aquades 3 hari pengujian

Gambar 5.1 - 5.7 merupakan hasil plot data ketujuh sampel untuk setiap pengulangan harinya, dengan tampilan radar masih terlihat nilai yang masih saling berimpit untuk satu sampel yang sama, walau sudah dibedakan dengan pengambilan data dari hari yang berbeda.

3. Kurva radar sampel positif kanker terhadap sampel yang negatif kanker dan aquades

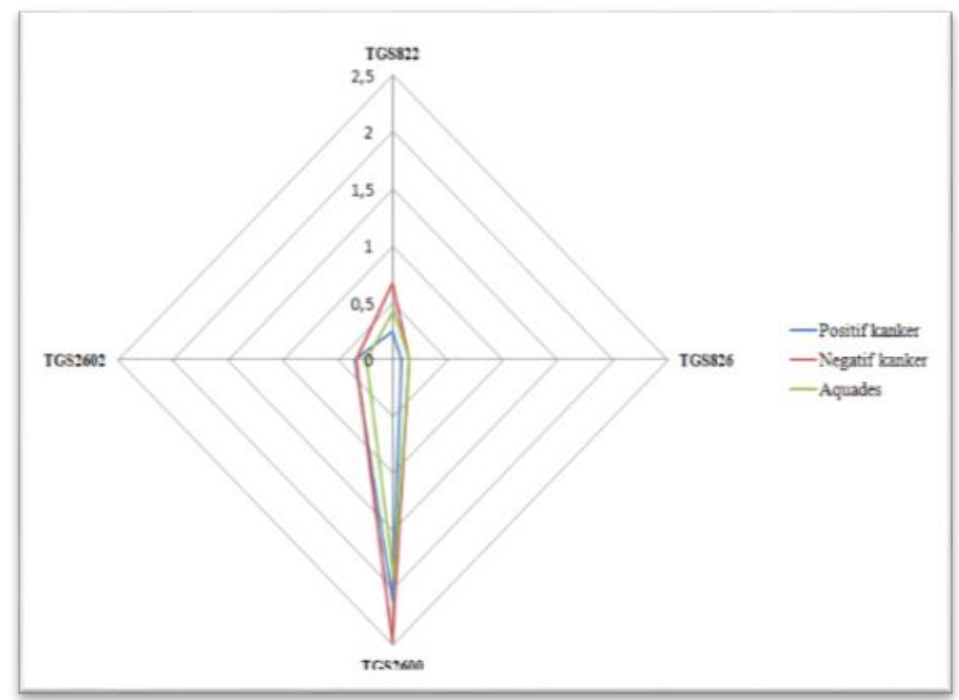

Gambar 6 Kurva radar sampel positif kanker terhadap sampel yang negatif kanker dan aquades

Gambar 6 merupakan gambar hasil gabungan dari respon luaran sensor dari tiga jenis sampel, yaitu sampel urin negatif kanker, urin positif kanker dan air. Pada Gambar 6 data dari e-nose sudah mampu memperlihatkan perbedaan keluaran sensor dari sampel yang berbeda terlihat dari terbentuknya 3 pola berbeda

\section{KESIMPULAN}

Dari penelitian yang telah dilakukan mengenai rancang bangun sistem electronic nose (enose) untuk deteksi kanker payudara berbasis mikrokontroler arduino uno, dapat ditarik kesimpulan. E-nose yang dirancang mampu mengenali sampel, terlihat dari nilai keluaran sensor dalam bentuk pola radar yang berimpit dengan nilai untuk semua sampel urin kanker payudara walaupun dari penderita berbeda. Masing-masing nilai keluaran ke 
empat sensornya TGS822, TGS826,TGS2600,TGS2602 secara berurutan yaitu pada penderita A $(0.14,0.07,2.03,0.27)$, penderita B $(0.13,0.07,1.97,0.30)$ dan pada penderita $\mathrm{C}(0.25,0.07,2.10,0.34)$. Begitupun saat diujikan pada urin negatif dan aquades pola berimpit dan E-nose yang dirancang mampu membedakan sampel urin positif kanker payudara, sampel urin negatif kanker payudara serta air. Semua hasil ini menunjukkan bahwa analisis electronic nose merupakan metode yang efisien membedakan sampel yang berbeda jenis (Zhang dkk, 2009).

\section{DAFTAR PUSTAKA}

1. Amico, A., Santonico, M., Pennazza, G., Capuano, R., Vespasiani, G., Fabbro, D.D., Paolesse, R., Natale, C.D., Martinelli, E. dan Agro, E.F., 2012, Anovel Approach for Prostate Cancer Diagnosis Using a Gas Sensor Array, Procedia Engineering, Vol 47, hal 1113-1116

2. Li, J., Peng, Y., Liu, Y., Li, W., Jin, Y., Tang, Z., Duan, Y., 2014, Investigation of Potential Breath Biomarkers for The Early Diagnosis of Breast Cancer Using Gas Chromatography-Mass Spectrometry,Clinica Chimica Acta, Elsevier, Vol 436, hal 59-67

3. Pan, L., Zhang, W., Zhu, N., Mao, S., dan Tu, K., 2014, Early detection and classification of pathogenic fungal disease in post-harvest strawberry, Food Research International, Vol 62, hal 162-168.

4. Peris, M. Dan Gilabert, L.E., 2009, A 21 st Century Technique for Food Control: Electronic Nose, Analytica Chimica Acta, Vol 638, hal 1-15.

5. Siyang, S., Kerdcharoen, T. dan Wongchoosuk, C., 2012, Diabetes Diagnosis by Direct Measurement from Urine Odor Using Electronic Nose, The 2012 Biomedical Engineering International Conference (BMEiCON-2012) IEEE.

6. Willis, C.M., Britton, L.E., Harris, R., Wallace, J. dan Guest, C., 2011, Volatile Organic Compounds as Biomarkers of Bladdes Cancer: Sensitivity and Specificity Using Trained Sniffer Dogs, Cancer Biomarkers,Vol 8, hal 145153.

7. Zakaria, A. 2012., Improved Maturity and Ripeness Classifications of Magnifera Indica cv. Harumanis Mangoes through Sensor Fusion of an Electronic Nose and Acoustic Sensor,Sensors, Vol 12, hal 6023-6048, ISSN:1424-8220.

8. Zhang, S. Xie, C. Bai, Z. Hu,M. Li,H. Zeng, D., 2008. Spoiling and formaldehyde-containing detections in octopus with an E-nose, Food Chemistry, Elsevier,Vol 113, hal 1346-1350 